\title{
Sorption properties of separate granulometric fractions in Haplic Cambisol
}

\author{
Zygmunt Brogowski and Józef Chojnicki* \\ Faculty of Agriculture and Biology, Department of Soil Environment Sciences, Division of Soil Sciences, Warsaw University of Life
} Sciences-SGGW, Nowoursynowska 159, 02-776 Warszawa, Poland

Received February 24, 2018; accepted November 4, 2018

\begin{abstract}
A b s t r a c t. The research was focused on testing the sorption properties of granulometric fractions isolated from genetic horizons of Haplic Cambisol developed from old-alluvial deposits of the Vistula River valley. The granulometric fractions were isolated using the Atterberg method, without centrifugation and application chemical peptizers. Granulometric fraction exchangeable sorption capacity was particularly similar to the fraction of soils developed from post-glacial rocks in the studied soil. The cation exchange capacity of the granulometric fractions increased with decrease of grain dimensions with mean value in cmol $(+) \mathrm{kg}^{-1}$ and contribution in particular fractions at $1-0.1 \mathrm{~mm}-0.89(0.9 \%)$, 0.1-0.02 mm - 2.3 (2.2\%), 0.01-0.02 mm - 7.91 (8.0\%), 0.01$0.005 \mathrm{~mm}-16.17(15.6 \%), 0.005-0.002 \mathrm{~mm}-27.6(27.6 \%)$ and $<0.002 \mathrm{~mm}-78.98(45.7 \%)$. Sorption properties of the examined soil determine its high agricultural value and resistance to chemical degradation. The dominating cations in the particular granulometric fractions sorption complex were exchangeable calcium and hydrogen, and the leaching process reduced the granulometric fraction calcium content in the surface levels and at the same time increased the hydrogen content. Leaching process intensity in individual fractions decreased gradually as their dimensions decreased, which explains the high susceptibility of coarsegrained soils (sandy soils) to this process.

$\mathrm{K}$ e y w o r d s: granulometric fractions, cation exchange capacity
\end{abstract}

\section{INTRODUCTION}

Soil granulometric composition has great influence on sorption (Skic et al., 2016; Czaban et al., 2014), physical features (Brogowski and Kwasowski, 2015; Brogowski et al., 2014; Rafraf et al., 2016; Malik et al., 2014), biological properties (Stemmer et al., 1998), soil typology (Kozłowski and Komisarek, 2017a, b; Musztyfaga and Kabała, 2015) and determines soil fertility and management (Kalembasa et al., 2011). So far, to recognize the role of grain size, extensive studies were performed on

\footnotetext{
*Corresponding author e-mail: jozef_chojnicki@sggw.pl
}

the sorption properties of particular granulometric fractions (Okołowicz, 1996; Asadu et al., 1997) and analysis of surface microstructures to understand the weathering process and formation of sorption properties (Morrás, 1995; Brogowski and Kocoń, 1984). These studies allow for further recognition of the mechanisms of sorption, desorption, migration of macro- and microelements (Jović et al., 2017), heavy metals (Dąbkowska-Naskręt et al., 2016; Roth et al., 2012) and other harmful substances (Korobova et al., 2014). The results of these investigations may contribute to the limitation of the mobility of elements and harmful substances in the environment and their leakage into the food chain. It should be emphasized that while soil science literature (Polish and international) supplies numerous data on the sorption properties determined in the entire soil mass (Chojnicki, 2002; Labaz and Kabala, 2016; Scarciglia et al., 2011) there are rather few studies devoted to the sorption capacity of particular granulometric fractions (Okołowicz, 1996; Soares et al., 2005). One of the reasons is the time-consuming and labour-intensive analytical process of distinguishing particular granulometric fractions from the solid phase of soils without centrifugation and use of chemical peptizers.

The research focused on testing the sorption properties of particular granulometric fractions distinguished from the genetic horizons of Haplic Cambisol. This is cultivated soil developed from old-alluvial deposits of the Vistula valley, which represents fertile farmland covering about 0.8 million ha of Poland (Chojnicki, 2002; DąbkowskaNaskręt, 1990). Deeper knowledge of the sorption properties of these soils is of great importance for their rational agricultural utilisation and environmental protection. Sorptive properties of soils and fractions are the basis

(C) 2019 Institute of Agrophysics, Polish Academy of Sciences 
for the application of an appropriate technology for their fertilization and minimizing the washout of biogens into the environment (ground and surface waters). They also determine the possibility of sorbing harmful compounds of active pesticide substances (Martins et al., 2018; Singh et al., 2014) and heavy metals (Roth et al., 2012).

\section{MATERIALS AND METHODS}

The studied soil according to FAO-WRB classification (IUSS Working Group WRB, 2015) was defined as Haplic Cambisol and is located in Kazuń Polski (52 $22^{\circ}$ '08.5 'N $20^{\circ} 40^{\prime} 46.2^{\prime \prime} \mathrm{E}$ ) about $40 \mathrm{~km}$ north of Warsaw. Fieldwork including profile description and sampling was carried out according to Jahn et al. (2006). The granulometric fractions were distinguished using the Atterberg method (USDA SCS, 1992) without application of chemical compounds for peptization. Peptization was performed using the thermal-mechanical technique by boiling soil with redistilled water $(0.5 \mathrm{~h})$ and mixing with a rotary agitator for about 10 minutes. Boiling and mixing was repeated till complete isolation of the $<0.002 \mathrm{~mm}$ fraction. The $>0.002$ $\mathrm{mm}$ fractions were isolated similarly, but without further boiling, whereas the $1-0.1 \mathrm{~mm}$ fraction was separated on sieves after drying. The fractions were dried in evaporators in a heated bath and further in a drier at the temperature of $80-90^{\circ} \mathrm{C}$. The granulometric composition was calculated from the content of the distinguished granulometric fractions after drying and weighing.
Laboratory analysis determined $\mathrm{pH}$ in distilled water and $1 \mathrm{M} \mathrm{KCl}$, potentiometrically, at a soil:liquid ratio of 1:2.5 $(\mathrm{v} / \mathrm{v})$, total organic carbon (TOC) using the Tiurin method. Due to the lack of calcium and/or magnesium carbonates in the soils, total carbon is equivalent to TOC. Total fraction and soil potential acidity $(\mathrm{H})$ was determined by means of the Kappen method (extraction using $1 \mathrm{~mol} \mathrm{dm}^{-3}$ calcium acetate and titration using $0.1 \mathrm{~mol} \mathrm{dm}^{-3} \mathrm{NaOH}$ ), exchangeable base cations $\left(\mathrm{Ca}^{2+}, \mathrm{K}+, \mathrm{Mg}^{2+}, \mathrm{Na}^{+}\right)$were extracted using $1 \mathrm{M}$ ammonium acetate at $\mathrm{pH}=7$ and analyzed by atomic absorption spectrometer (Thermoelemental SOLAAR M6). The cation exchange capacity (CEC) and base saturation (BS) were calculated based on the sum of total exchangeable base cations (BC) and the potential acidity $(\mathrm{H})$. For evaluation of relationships between cation exchange capacity and fraction diameter analysis of regression was applied.

\section{RESULTS AND DISCUSSION}

To the depth of $150 \mathrm{~cm}$, the studied soil shows a granulometric fraction of sandy loam underlain by sand (Table 1 ). The fine sand fraction $(0.25-0.1 \mathrm{~mm})$ dominates in the entire profile, whereas coarse sand (1-0.5 mm) occurs in trace quantities. Acidic reaction observed in the surface horizons changes into poorly acidic with depth while the saturation of the sorption complex by alkaline cations (BS) increases with depth (Table 2). The investigated soil shows a low total organic carbon content, the quantity of which

Table 1. Particle size distribution of soil

\begin{tabular}{|c|c|c|c|c|c|c|c|c|c|c|}
\hline \multirow[b]{2}{*}{ Horizon } & \multirow[b]{2}{*}{$\begin{array}{c}\text { Depth } \\
(\mathrm{cm})\end{array}$} & \multicolumn{9}{|c|}{$\%$ Diameter content fractions $(\mathrm{mm})$} \\
\hline & & $1-0.5$ & $0.5-0.25$ & $0.25-0.1$ & $0.1-0.05$ & $0.05-0.02$ & $0.02-0.01$ & $\begin{array}{l}0.01- \\
0.005\end{array}$ & $\begin{array}{c}0.005- \\
0.002\end{array}$ & $<0.002$ \\
\hline A & $5-30$ & 1.0 & 7.1 & 33.2 & 13.1 & 18.0 & 6.7 & 4.3 & 3.5 & 13.0 \\
\hline $\mathrm{ABw}$ & $30-50$ & 1.1 & 6.3 & 34.9 & 13.3 & 18.9 & 6.5 & 3.1 & 3.5 & 12.4 \\
\hline Bw & $50-70$ & 0.5 & 3.8 & 27.7 & 13.0 & 15.6 & 6.2 & 3.4 & 4.1 & 24.4 \\
\hline $\mathrm{BwC}$ & $70-90$ & 0.2 & 1.0 & 30.6 & 34.8 & 11.6 & 2.1 & 2.3 & 1.6 & 15.8 \\
\hline $\mathrm{C}$ & $90-120$ & 0.2 & 2.8 & 48.7 & 14.6 & 14.3 & 2.7 & 1.8 & 1.4 & 13.5 \\
\hline $\mathrm{C}$ & $120-150$ & 0.2 & 5.0 & 40.0 & 16.3 & 18.4 & 3.1 & 1.9 & 2.4 & 12.7 \\
\hline IIC & $150-175$ & 0.3 & 20.2 & 46.4 & 11.0 & 12.7 & 4.0 & 0.6 & 1.0 & 3.8 \\
\hline IIC & $175-200$ & 0.2 & 26.1 & 52.6 & 10.2 & 4.6 & 0.8 & 0.5 & 0.6 & 4.4 \\
\hline \multicolumn{2}{|c|}{ Average } & 0.5 & 9.0 & 39.3 & 15.8 & 14.3 & 4.0 & 2.2 & 2.3 & 12.6 \\
\hline
\end{tabular}

Table 2. Physicochemical properties of soil

\begin{tabular}{|c|c|c|c|c|c|c|c|c|c|c|c|c|}
\hline \multirow{2}{*}{ Horizon } & \multirow{2}{*}{$\begin{array}{c}\text { Depth } \\
(\mathrm{cm})\end{array}$} & \multicolumn{2}{|c|}{$\mathrm{pH}$} & $\mathrm{Ca}^{2+}$ & $\mathrm{Mg}^{2+}$ & $\mathrm{K}^{+}$ & $\mathrm{Na}^{+}$ & TEB & $\mathrm{H}^{+}$ & CEC & BS & TOC \\
\hline & & $\mathrm{H}_{2} \mathrm{O}$ & $\mathrm{KCl}$ & \multicolumn{7}{|c|}{$\mathrm{cmol}(+) \mathrm{kg}^{-1}$ of soil } & \multicolumn{2}{|c|}{$(\%)$} \\
\hline A & $5-30$ & 5.0 & 4.0 & 2.17 & 0.78 & 0.10 & 0.14 & 3.19 & 2.84 & 6.03 & 52.9 & 0.70 \\
\hline $\mathrm{ABw}$ & $30-50$ & 5.4 & 4.1 & 3.60 & 1.47 & 0.11 & 0.23 & 5.41 & 2.47 & 7.88 & 68.6 & 0.19 \\
\hline Bw & $50-70$ & 5.6 & 4.1 & 6.30 & 2.13 & 0.14 & 0.30 & 8.87 & 2.28 & 11.15 & 79.5 & 0.18 \\
\hline BwC & $70-90$ & 5.7 & 4.2 & 7.80 & 2.37 & 0.17 & 0.47 & 10.81 & 2.81 & 13.62 & 79.4 & 0.17 \\
\hline C & $90-120$ & 5.7 & 4.2 & 4.82 & 1.00 & 0.11 & 0.63 & 6.56 & 1.62 & 8.18 & 80.2 & 0.05 \\
\hline $\mathrm{C}$ & $120-150$ & 5.6 & 4.3 & 6.15 & 1.08 & 0.14 & 0.63 & 8.00 & 1.50 & 9.50 & 84.2 & 0.07 \\
\hline IIC & $150-175$ & 6.4 & 5.5 & 4.83 & 1.00 & 0.10 & 0.45 & 6.37 & 0.82 & 7.20 & 88.6 & 0.02 \\
\hline IIC & $175-200$ & 6.9 & 6.1 & 2.87 & 0.40 & 0.07 & 0.09 & 3.43 & 0.50 & 3.93 & 87.3 & 0.01 \\
\hline
\end{tabular}


gradually decreases with depth in the profile, whereas the cation exchange capacity varies in particular horizons and is related to their granulometric composition.

The cation exchange capacity of soil depends on its granulometric composition and type of sorbents within the granulometric fractions (clay minerals, humus compounds, iron and manganese oxides). The quantitative and qualitative composition of exchangeable cations in soils depends also on the energy of bonds between particular cations.

In the studied soil, exchangeable calcium is bound by the clay fraction $<0.002 \mathrm{~mm}$, which sorbs averagely up to $62.1 \%$ of this element (Fig. 1) and varies between 58.3 and $66.2 \%$ (Table 3 ). The remaining five fractions $1-0.002 \mathrm{~mm}$ contain only $33.8 \%$ of exchangeable calcium, with the following contents in particular fractions: $1-0.02 \mathrm{~mm}-2.2 \%$, $0.02-0.01 \mathrm{~mm}-6.0 \%, 0.01-0.005 \mathrm{~mm}-11.6 \%$ and $0.005-$ $0.002 \mathrm{~mm}-18.1 \%$. The contribution of the $1-0.002 \mathrm{~mm}$ fractions binding calcium increases gradually whereas significant increase occurs in the $<0.002 \mathrm{~mm}$ fraction. In the entire profile, the richest in exchangeable fraction are most granulometric fractions from the arable-humus horizon and the fraction from the deepest parts of the profile. Gradual increase of the exchangeable calcium content in the fractions with depth is the result of leaching processes. These processes occur only partly within the $0.02-0.01$ and 0.01-0.005 $\mathrm{mm}$ fractions from the $\mathrm{BwC}$ horizon, which are rich in exchangeable calcium. At the same time the 0.005-0.002 and $<0.002 \mathrm{~mm}$ fractions contain the smallest amount of this element.

The content of exchangeable magnesium increases with smaller size of the granulometric fractions and is much lower than that of calcium (Table 3). The 1-0.02 mm fraction, averagely contributing to $80 \%$ of the soil mass (Table 1), averagely bonds only $1.3 \%$ of this element (Fig. 1). The significantly highest average contribution in binding magnesium have the smallest fractions: $<0.002 \mathrm{~mm}$ $-56.0 \%$, varying from 44.8 to $67.1 \%$ and $0.005-0.002 \mathrm{~mm}$ $-26.7 \%$, varying from 12.5 to $36.9 \%$ in the soil profile

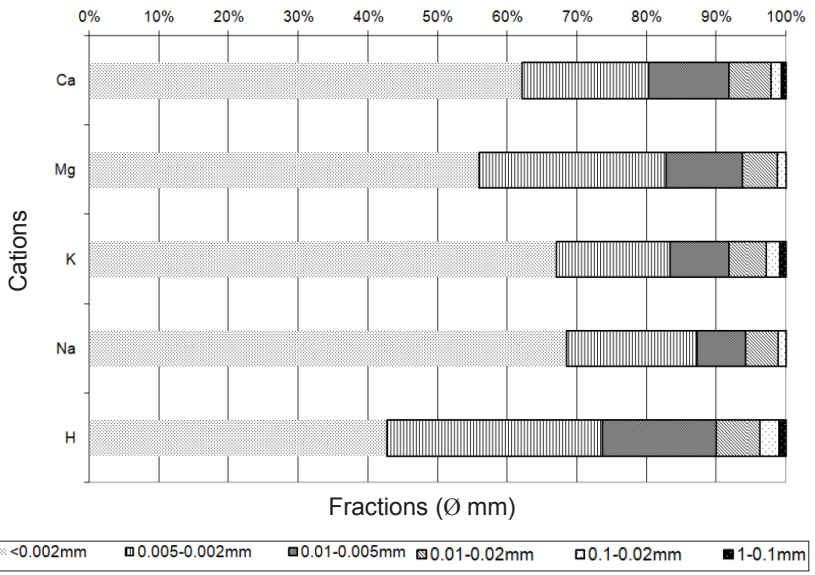

Fig. 1. Average percentage share of the fractions in sorption of the exchangeable cations.
(Table 3). The 0.02-0.01 mm, 0.01-0.005 $\mathrm{mm}$ and 0.005$0.002 \mathrm{~mm}$ fractions isolated from horizon $\mathrm{BwC}$ and parent rock $\mathrm{C}$ reveal the highest contribution of exchangeable magnesium, similarly as calcium, in comparison to these fractions from the remaining horizons in the soil profile. In turn, the highest content of exchangeable magnesium in the $<0.002 \mathrm{~mm}$ fraction was observed in the surface humus horizon, where it is twice as large in this fraction as in the remaining horizons.

The content of exchangeable potassium, similarly as of the remaining fractions, increases gradually from the coarsest to the finest fractions at a very significant increase of its contribution in the $<0.002 \mathrm{~mm}$ fraction (Table 3 ). Therefore the percentage content of the particular granulometric fractions in the accumulation of exchangeable potassium reaches averagely: $1.0-0.02 \mathrm{~mm}-2.9 \%, 0.02-0.002 \mathrm{~mm}-30.0 \%$ and colloidal clay $67 \%$, varying from 54.0 to $82.9 \%$ in the soil profile (Fig. 1, Table 3). All fractions isolated from the humus horizon were definitely richer in exchangeable potassium in comparison to fractions from deeper soil horizons. The only exceptions are the $0.02-0.01 \mathrm{~mm}$ and $0.01-0.005 \mathrm{~mm}$ fractions from the $\mathrm{BwC}$ horizons, in which high contents of the exchangeable forms of this element, similarly as calcium and magnesium, were noted. Migration of exchangeable potassium in deeper parts of the soil profile were not observed in any of the analyzed fractions, whereas its significant accumulation in fractions from the humus horizon results from bioaccumulation and fertilizing.

The content of exchangeable sodium is much higher that the content of exchangeable potassium in the studied soil fractions (Table 3). The content and percentage contribution of particular fractions in the sorption of exchangeable sodium increases with decreasing grain dimensions. As a result, the following average content of particular fractions was noted in this process: $1-0.02 \mathrm{~mm}-1.1 \%, 0.02-0.002$ $\mathrm{mm}-30.3 \%$ and $<0.002 \mathrm{~mm}-68.5 \%$ (Fig. 1). In the soil profile, the highest contents of exchangeable sodium occur in fractions from the surface humus horizon, to decrease gradually to the depth of $175 \mathrm{~cm}$, and increase again in the particular fractions in the deepest part of the profile.

The content of exchangeable hydrogen, similarly as in the case of the cations presented above, increases in the particular granulometric fractions with grain dimensions (Table 3). However, the increase of the hydrogen content is gradual in particular fractions, with a much less dominating content of the clay fraction (Fig. 1). The average contributions of fractions in the sorption of exchangeable hydrogen are as follows: $1-0.02 \mathrm{~mm}-3.8 \%, 0.02-0.002 \mathrm{~mm}-53.5 \%$ and $<0.002 \mathrm{~mm}-42.7 \%$. The leaching process has caused the highest contents of exchangeable hydrogen to occur in all fractions of the surface humus horizon and to successively decrease with depth. The largest decrease of the hydrogen content with depth of the soil profile was observed 
Table 3. Exchangeable cations content in granulometric fractions and their percentage share

\begin{tabular}{|c|c|c|c|c|c|c|c|c|c|c|c|c|c|}
\hline \multirow{2}{*}{ Horizon } & \multirow{2}{*}{$\begin{array}{l}\text { Depth } \\
(\mathrm{cm})\end{array}$} & \multicolumn{6}{|c|}{$\mathrm{cmol}(+) \mathrm{kg}^{-1}$ of fractions in diameter $(\mathrm{mm})$} & \multicolumn{6}{|c|}{$\%$ share of fractions diameter $(\mathrm{mm})$} \\
\hline & & $1-0.1$ & $\begin{array}{l}0.1- \\
0.02\end{array}$ & $\begin{array}{c}0.02- \\
0.01\end{array}$ & $\begin{array}{l}0.01- \\
0.005\end{array}$ & $\begin{array}{c}0.005- \\
0.002\end{array}$ & $<0.002$ & $1-0.1$ & $\begin{array}{l}0.1- \\
0.02\end{array}$ & $\begin{array}{c}0.02- \\
0.01\end{array}$ & $\begin{array}{l}0.01- \\
0.005\end{array}$ & $\begin{array}{c}0.005- \\
0.002\end{array}$ & $<0.002$ \\
\hline \multicolumn{14}{|c|}{$\mathrm{Ca}^{2+}$} \\
\hline A & $5-30$ & 0.67 & 1.73 & 5.42 & 13.60 & 13.70 & 60.94 & 0.7 & 1.8 & 5.6 & 14.2 & 14.3 & 63.4 \\
\hline $\mathrm{ABw}$ & $30-50$ & 0.62 & 0.93 & 3.60 & 6.34 & 14.05 & 50.14 & 0.8 & 1.2 & 4.8 & 8.4 & 18.6 & 66.2 \\
\hline Bw & $50-70$ & 0.58 & 0.90 & 3.12 & 7.00 & 17.10 & 47.72 & 0.8 & 1.2 & 4.1 & 9.2 & 22.4 & 62.3 \\
\hline BwC & $70-90$ & 0.44 & 0.74 & 6.15 & 8.95 & 8.84 & 35.32 & 0.7 & 1.2 & 10.2 & 14.8 & 14.6 & 58.3 \\
\hline $\mathrm{C}$ & $90-120$ & 0.33 & 1.00 & 4.06 & 7.45 & 13.72 & 46.60 & 0.4 & 1.4 & 5.5 & 10.2 & 18.8 & 63.7 \\
\hline $\mathrm{C}$ & $120-150$ & 0.51 & 1.32 & 3.75 & 9.25 & 14.50 & 45.43 & 0.7 & 1.8 & 5.0 & 12.4 & 19.4 & 60.7 \\
\hline IIC & $150-175$ & 0.51 & 1.68 & 5.60 & 11.00 & 16.20 & 52.80 & 0.6 & 1.9 & 6.4 & 12.5 & 18.5 & 60.1 \\
\hline IIC & $175-200$ & 0.53 & 1.70 & 6.25 & 11.00 & 18.00 & 62.21 & 0.5 & 1.7 & 6.3 & 11.0 & 18.1 & 62.4 \\
\hline \multicolumn{14}{|c|}{$\mathrm{Mg}^{2+}$} \\
\hline A & $5-30$ & 0.05 & 0.15 & 0.87 & 4.00 & 3.12 & 16.72 & 0.2 & 0.6 & 3.5 & 16.1 & 12.5 & 67.1 \\
\hline $\mathrm{ABw}$ & $30-50$ & 0.04 & 0.17 & 0.41 & 1.08 & 3.78 & 6.95 & 0.3 & 1.4 & 3.3 & 8.7 & 30.4 & 55.9 \\
\hline Bw & $50-70$ & 0.03 & 0.10 & 0.80 & 2.16 & 5.33 & 8.75 & 0.2 & 0.6 & 4.7 & 12.6 & 36.9 & 45.0 \\
\hline BwC & $70-90$ & 0.05 & 0.06 & 2.02 & 2.62 & 4.32 & 7.80 & 0.3 & 0.4 & 12.0 & 15.5 & 25.6 & 46.2 \\
\hline $\mathrm{C}$ & $90-120$ & 0.07 & 0.25 & 1.23 & 2.00 & 4.50 & 6.52 & 0.5 & 1.7 & 8.4 & 13.7 & 30.9 & 44.8 \\
\hline $\mathrm{C}$ & $120-150$ & 0.04 & 0.17 & 0.38 & 0.92 & 2.77 & 7.22 & 0.3 & 1.5 & 3.3 & 8.0 & 24.1 & 62.8 \\
\hline IIC & $150-175$ & 0.03 & 0.15 & 0.24 & 0.71 & 4.00 & 9.30 & 0.2 & 1.0 & 1.7 & 4.9 & 27.7 & 64.5 \\
\hline IIC & $175-200$ & 0.03 & 0.11 & 0.34 & 1.03 & 3.22 & 7.90 & 0.2 & 0.9 & 2.7 & 8.2 & 25.5 & 62.5 \\
\hline \multicolumn{14}{|c|}{$\mathrm{K}^{+}$} \\
\hline A & $5-30$ & 0.10 & 0.19 & 0.42 & 1.10 & 0.73 & 12.40 & 0.7 & 1.3 & 2.8 & 7.4 & 4.9 & 82.9 \\
\hline $\mathrm{ABw}$ & $30-50$ & 0.10 & 0.16 & 0.23 & 0.31 & 0.80 & 4.20 & 1.7 & 2.8 & 4.0 & 5.3 & 13.8 & 72.4 \\
\hline Bw & $50-70$ & 0.06 & 0.12 & 0.22 & 0.26 & 0.70 & 2.37 & 1.6 & 3.2 & 5.9 & 7.0 & 18.8 & 63.5 \\
\hline BwC & $70-90$ & 0.03 & 0.07 & 0.54 & 0.68 & 0.70 & 2.38 & 0.7 & 1.6 & 12.3 & 15.5 & 15.9 & 54.0 \\
\hline $\mathrm{C}$ & $90-120$ & 0.04 & 0.07 & 0.18 & 0.23 & 0.35 & 2.09 & 1.3 & 2.4 & 6.1 & 7.8 & 11.8 & 70.6 \\
\hline $\mathrm{C}$ & $120-150$ & 0.01 & 0.01 & 0.06 & 0.12 & 0.41 & 1.24 & 0.5 & 0.5 & 3.2 & 6.5 & 22.2 & 67.1 \\
\hline IIC & $150-175$ & 0.01 & 0.02 & 0.10 & 0.20 & 0.48 & 1.36 & 0.5 & 0.9 & 4.6 & 9.2 & 22.1 & 62.7 \\
\hline IIC & $175-200$ & 0.01 & 0.04 & 0.07 & 0.15 & 0.35 & 1.08 & 0.6 & 2.4 & 4.1 & 8.8 & 20.6 & 63.5 \\
\hline \multicolumn{14}{|c|}{$\mathrm{Na}^{+}$} \\
\hline A & $5-30$ & 0.09 & 0.32 & 2.80 & 2.70 & 2.86 & 14.75 & 0.4 & 1.4 & 11.9 & 11.5 & 12.2 & 62.6 \\
\hline $\mathrm{ABw}$ & $30-50$ & 0.03 & 0.12 & 0.34 & 0.48 & 2.40 & 5.65 & 0.3 & 1.3 & 3.8 & 5.3 & 26.6 & 62.7 \\
\hline Bw & $50-70$ & 0.02 & 0.10 & 0.32 & 0.54 & 1.25 & 2.34 & 0.4 & 2.2 & 7.0 & 11.8 & 27.4 & 51.2 \\
\hline BwC & $70-90$ & 0.02 & 0.03 & 0.24 & 0.36 & 0.92 & 1.81 & 0.6 & 0.9 & 7.1 & 10.6 & 27.2 & 53.6 \\
\hline $\mathrm{C}$ & $90-120$ & 0.01 & 0.04 & 0.16 & 0.36 & 1.47 & 5.36 & 0.1 & 0.5 & 2.2 & 4.9 & 19.9 & 72.4 \\
\hline $\mathrm{C}$ & $120-150$ & 0.01 & 0.02 & 0.11 & 0.21 & 1.08 & 7.40 & 0.1 & 0.2 & 1.2 & 2.4 & 12.2 & 83.9 \\
\hline IIC & $150-175$ & 0.01 & 0.03 & 0.08 & 0.17 & 1.08 & 8.20 & 0.1 & 0.3 & 0.8 & 1.8 & 11.3 & 85.7 \\
\hline IIC & $175-200$ & 0.00 & 0.08 & 0.32 & 0.84 & 1.40 & 8.16 & 0.0 & 0.7 & 3.0 & 7.8 & 13.0 & 75.5 \\
\hline \multicolumn{14}{|c|}{$\mathrm{H}^{+}$} \\
\hline A & $5-30$ & 0.52 & 2.12 & 3.28 & 6.32 & 10.24 & 14.60 & 1.4 & 5.7 & 8.8 & 17.0 & 27.6 & 39.5 \\
\hline $\mathrm{ABw}$ & $30-50$ & 0.28 & 0.90 & 2.17 & 5.18 & 9.18 & 11.80 & 0.9 & 3.0 & 7.4 & 17.6 & 31.1 & 40.0 \\
\hline Bw & $50-70$ & 0.36 & 0.83 & 2.18 & 4.31 & 8.16 & 10.12 & 1.4 & 3.2 & 8.4 & 16.6 & 31.4 & 39.0 \\
\hline BwC & $70-90$ & 0.25 & 0.61 & 2.14 & 3.95 & 9.37 & 12.13 & 0.9 & 2.1 & 7.5 & 13.9 & 32.9 & 42.7 \\
\hline $\mathrm{C}$ & $90-120$ & 0.17 & 0.50 & 1.02 & 2.82 & 6.31 & 8.18 & 0.9 & 2.6 & 5.4 & 14.8 & 33.2 & 43.1 \\
\hline $\mathrm{C}$ & $120-150$ & 0.19 & 0.37 & 0.84 & 3.20 & 4.82 & 9.24 & 1.0 & 2.0 & 4.5 & 17.1 & 25.8 & 49.6 \\
\hline IIC & $150-175$ & 0.15 & 0.28 & 0.76 & 2.56 & 5.26 & 7.31 & 0.9 & 1.7 & 4.7 & 15.7 & 32.2 & 44.8 \\
\hline IIC & $175-200$ & 0.14 & 0.21 & 0.45 & 2.20 & 4.12 & 5.34 & 1.1 & 1.7 & 3.6 & 17.7 & 33.1 & 42.8 \\
\hline
\end{tabular}


Table 4. Cation exchange capacity of granulometric fractions

\begin{tabular}{lccccccc}
\hline & & \multicolumn{5}{c}{$\mathrm{cmol}(+) \mathrm{kg}^{-1}$ of fractions in diameter $(\mathrm{mm})$} \\
\cline { 3 - 7 } Horizon & $\begin{array}{c}\text { Depth } \\
(\mathrm{cm})\end{array}$ & $1-0.1$ & $0.1-0.02$ & $0.02-0.01$ & $0.01-0.005$ & $0.005-0.002$ & $<0.002$ \\
\hline $\mathrm{A}$ & $5-30$ & 1.43 & 4.51 & 12.80 & 27.71 & 30.65 & 119.41 \\
$\mathrm{ABw}$ & $30-50$ & 1.07 & 2.28 & 6.75 & 13.40 & 30.21 & 78.74 \\
$\mathrm{Bw}$ & $50-70$ & 1.05 & 2.05 & 6.64 & 14.27 & 32.54 & 71.30 \\
$\mathrm{BwC}$ & $70-90$ & 0.80 & 1.45 & 11.09 & 16.56 & 24.15 & 59.44 \\
$\mathrm{C}$ & $90-120$ & 0.62 & 1.86 & 6.65 & 12.86 & 26.35 & 68.75 \\
$\mathrm{C}$ & $120-150$ & 0.76 & 1.90 & 5.14 & 13.70 & 23.18 & 70.53 \\
$\mathrm{IIC}$ & $150-175$ & 0.71 & 2.16 & 6.78 & 14.64 & 27.02 & 78.97 \\
$\mathrm{IIC}$ & $175-200$ & 0.71 & 2.13 & 7.43 & 15.22 & 27.09 & 84.69 \\
\hline
\end{tabular}

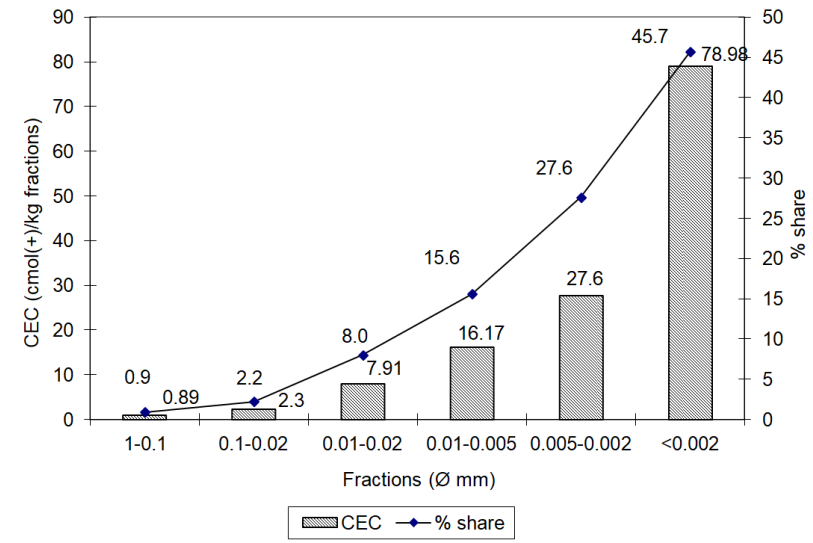

Fig. 2. Average cation exchange capacity (CEC) of the isolated fractions and their percentage contribution.

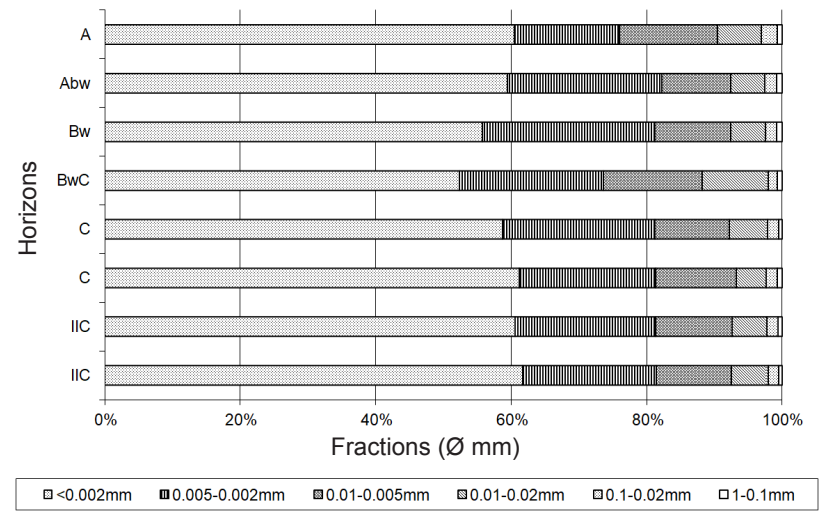

Fig. 3. Percentage contribution of the isolated fractions in the cation exchange capacity.

successively in the following fractions: $0.1-0.02 \mathrm{~mm}$ $>0.02-0.01 \mathrm{~mm}>1-0.1 \mathrm{~mm}$, whereas the remaining fractions did not show such a significant decrease.

The cation exchange capacity of the studied granulometric fractions increases with decreasing grain size (Table 4 , Figs 2 and 3) and this relationship is statistically significant

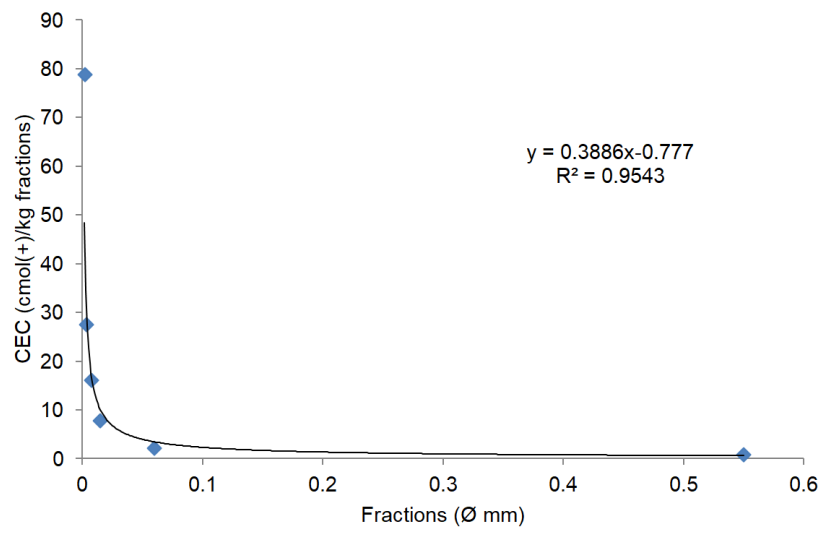

Fig. 4. Relationship between cation exchange capacity of the fractions and their diameter.

(Fig. 4). The average contribution of granulometric fractions in the cation exchange capacity is $1-0.02 \mathrm{~mm}-3.1 \%$ (from 0.7 to $2.8 \%$ ), $0.02-0.01 \mathrm{~mm}-8.0 \%$ (from 6.3 to $12.5 \%$ ), 0.01 $0.005 \mathrm{~mm}-15.6 \%$ (from 12.5 to $18.7 \%$ ), $0.005-0.002 \mathrm{~mm}$ $-27.6 \%$ (from $18.9 \%$ to $32.8 \%$ ) and fraction $<0.002 \mathrm{~mm}$ $-45.7 \%$, varying from 38.9 to $51.8 \%$. Similar values of cation exchange capacity were also observed in the granulometric fractions of soils in eastern Germany (Leinweber et al., 1993), in limestone soils in Spain (Caravaca et al., 1999), in some soils in the USA (Joffe and Kunin, 1943), Ireland (McAleese and McConaghy, 1957) and sand and loam soils in Poland (Okołowicz, 1996). The size of cation exchange capacity in the studied fractions was particularly similar to fractions in soils developed from glacial rocks. A significantly larger cation exchange capacity of all fractions in the humus horizon, as also confirmed by other authors (Asadu et al., 1997, Okołowicz, 1996), is caused by a content of humus in this horizon. The sorption properties of the soil and fractions determine its high agricultural value and limit leaching of mineral nutrients and harmful elements and compounds to other parts of the environment. Generally, the cation exchange capacity in particular horizons of the soil profile showed a relatively low variability. This points to substantial homogeneity of the grain size 
and mineral composition of the analyzed soil, developed from alluvial deposits, which very often indicate high variability of grain size (Chojnicki, 2002). Our studies and the reports of other authors indicate that the sorption properties of particular granulometric fractions depend on the origin and properties of the parent rock and the pedogenic processes. Of great significance are the mineral composition of the rocks, including properties and susceptibility of particular minerals to weathering, climate conditions, including temperature and humidity deciding on the intensity of weathering processes and the intensity and duration of pedogenic processes.

In the deeper part of the profile, some fractions from the $\mathrm{BwC}$ horizon indicate diverse sorption properties compared to fractions from the remaining horizons. The $0.02-0.01 \mathrm{~mm}$ and $0.01-0.005 \mathrm{~mm}$ fractions from this horizon are distinguished by a much larger cation exchange capacity, whereas the $0.005-0.002 \mathrm{~mm}$ and $<0.002 \mathrm{~mm}$ fractions have the smallest cation exchange capacity compared to the fractions from the remaining subsurface horizons. Large sorption capacity of silts fractions $(0.05-0.002 \mathrm{~mm})$ was also noted in some soils from Argentina (Morrás, 1995), Ireland (McAleese and Mitchell, 1958), Africa (Asadu et al., 1997), Brazil (Soares et al., 2005) and USA (Tedrow, 1966). These reports have indicated that high contributions of feldspars, micas and silicates in the silt fraction significantly increased its cation exchange capacity whereas the dominating contribution of quartz decreased the capacity of this fraction. Based on scanning electron microscope (SEM) and transmission electron microscope (TEM) analyses, Morrás (1995), and McAleese and Mitchell (1958) concluded that weathering micas (surface flaking, opening of inter-layer space) as transitional type of minerals between primary and secondary clay minerals have the greatest contribution in the sorption capacity of the silt fraction. These authors attributed the lower contribution in the capacity of this fraction to weathering feldspars, coatings of clay minerals and humus on the surface of silt grains, clay aggregates and biogenic silica. Soares et al. (2005) emphasize also the high possible contribution in the sorption capacity of mineral and organic colloids accumulated in grain caverns, formed during chemical weathering, in the silt and sand fractions. Extensive studies of soils from Brazil have indicated that not only silt but also sand fractions in soils developed from clay shales and basalt have a very high cation exchange capacity (Soares et al. 2005).

\section{CONCLUSIONS}

1. The cation exchange capacity of granulometric fractions in the studied Haplic Cambisol soil developed from old alluvial sediments was particularly similar to fractions in soils developed from glacial rocks. The cation exchange capacity of particular granulometric fractions increased with decreasing grain size; its average value in $\operatorname{cmol}(+)$ $\mathrm{kg}^{-1}$ and contribution in particular fractions was $1-0.1 \mathrm{~mm}$ - 0.89 (0.9\%), 0.1-0.02 mm - 2.3 (2.2\%), 0.01-0.02 mm - $7.91(8.0 \%), 0.01-0.005 \mathrm{~mm}-16.17$ (15.6\%), $0.005-$ $0.002 \mathrm{~mm}-27.6(27.6 \%)$ and $<0.002 \mathrm{~mm}-78.98(45.7 \%)$. Sorption properties of the examined soil determine its high agricultural value and resistance to chemical degradation.

2 . The dominant cations in the sorption complex of individual granulometric fractions were exchangeable calcium and hydrogen and the leaching process reduced the content of calcium in the granulometric fractions of the surface levels while at the same time increasing their hydrogen content. The intensity of the leaching process in individual fractions decreased successively as their dimensions decreased, which explains the high susceptibility of coarse-grained soils (especially sandy soils) to this process.

Conflict of interest: The Authors do not declare conflict of interest.

\section{REFERENCES}

Asadu C.L.A., Diels J., and Vanlauwe B., 1997. A comparison of the contributions of clay, silt, and organic matter to the effective CEC of soils of Subsaharan Africa. Soil Sci., 162 (11), 785-794.

Brogowski Z. and Kwasowski W., 2015. An attempt of using soil grain size in calculating the capacity of water unavailable to plants. Soil Sci. Ann., 66(1), 21-28.

Brogowski Z., Kwasowski W., and Madyniak R., 2014. Calculating particle density, bulk density, and total porosity of soil based on its texture. Soil Sci. Ann., 65(4), 139-149.

Brogowski Z. and Kocoń J., 1984. Morphology of surface of sand grains from different genetic horizons of brown soil developed from heavy loam. Rocz. Glebozn., 35(1), 115-124.

Caravaca F., Lax A., and Albaladejo J., 1999. Organic matter, nutrient contents and cation exchange capacity in fine fractions from semiarid calcareous soils. Geoderma, 93, 3-4: 161-176.

Chojnicki J., 2002. Soil - forming processes in alluvial soils of central Vistula valley and Żuławy. Publishing SGGW Warszawa, 1-83.

Czaban J., Czyż E., Siebielec G., and Niedźwiecki J., 2014. Long-lasting effects of bentonite on properties of a sandy soil deprived of the humus layer. Int. Agrophys., 28, 279-289.

Dąbkowska-Naskręt H., Różański S., and Bartkowiak A., 2016. Forms and mobility of trace elements in soils of park areas from the city of Bydgoszcz, north Poland. Soil Sci. Ann., 67(2), 73-78.

Dąbkowska-Naskręt H., 1990. Composition and physicochemical properties of selected alluvial soils of the Lower Vistula Valley taking into account their diagnostic features. Publishing ART Bydgoszcz, 1-117.

IUSS Working Group WRB, 2015. World Reference Base for Soil Resources 2014, update 2015. International soil classification system for naming soils and creating legends for soil maps. World Soil Resources Reports No. 106. FAO, Rome. 
Jahn H.P., Blume H.P., Asio V.B., Spaargaren O., Schad P., et al., 2006. Guidelines for Soil Description. FAO, Rome (2006), 97.

Joffe J. and Kunin R., 1943. Mechanical separates and their fractions in the soil profile. II. The cation exchange properties and pedogenic implications. Soil Sci. Soc. Am. Proc., 8, 384-387.

Jović M., Šljivić-Ivanović M., Dimović S., Marković J., and Smičiklas I., 2017. Sorption and mobility of Co(II) in relation to soil properties. Geoderma, 297, 38-47.

Kalembasa D., Pakula K., and Jaremko D., 2011. Sorption properties of soils in the Siedlce upland (in Polish). Acta Agrophysica, 18(2), 311-319.

Korobova E., Linnik V., Chizhikova N., Alekseeva T., Shkinev V., Brown J., and Dinu M., 2014. Granulometric and mineralogic investigation for explanation of radionuclide accumulation in different size fractions of the Yenisey floodplain soils. J. Geochemical Exploration, 142, 49-59.

Kozłowski M. and Komisarek J., 2017a. Textural diversity in selected Retisols in the catena of the Opalenica Plain (western Poland). Soil Sci. Ann., 68(1), 1-18.

Kozłowski M. and Komisarek J., 2017b. Analysis of the suitability of Polish soil texture classification for estimating soil water retention and hydraulic properties. Soil Sci. Ann., 68(4), 197-204.

Leinweber P., Reuter G., and Brozio K., 1993. Cation exchange capacities of organo-mineral particle-size fractions in soils from long-term experiments. J. Soil Sci., 44, 111-119.

Labaz B. and Kabala C., 2016. Human-induced development of mollic and umbric horizons in drained and farmed swampy alluvial soils. Catena, 139, 117-126.

Malik Z., Malik M., Yu-Tong Z., and Sheng-Gao L., 2014. Physical properties of unproductive soils of Northern China. Int. Agrophys., 28, 459-469.

Martins E., Melo V., Bohone J., and Gilberto Abate G., 2018. Sorption and desorption of atrazine on soils: The effect of different soil fractions. Geoderma, 322, 131-139.

McAleese D. and McConaghy S., 1957. Studies on the basaltic soils of Northern Ireland. I1. Contributions from the sand, silt and clay separates to cation exchange properties. J. Soil Sci., 8(1), 135-140.

McAleese D. and Mitchell W.A., 1958. Studies on the basaltic soils of Northern Ireland: V. Cation-exchange capacities and mineralogy of the silt separates $(2-20 \mu)$. J. Soil Sci., 9(1), 81-88.
Morra's H.J.M., 1995. Mineralogy and cation exchange capacity of the fine silt fraction in two soils from the southern Chaco Region Argentina. Geoderma, 64, 281-295.

Musztyfaga E. and Kabała C., 2015. Lithological discontinuity in Glossic Planosols (Albeluvisols) of Lower Silesia (SW Poland). Soil Sci. Ann., 66(4), 180-190.

Okolowicz M., 1996. Sorption capacity of particle size fractions of selected soils. Rocz.. Glebozn., 47, 1/2, 33-46.

Rafraf S., Guellouz L., Guiras H., and Bouhlila R., 2016. Quantification of hysteresis effects on a soil subjected to drying and wetting cycles. Int. Agrophys., 30, 493-499.

Roth E., Mancier V., and Fabre B., 2012. Adsorption of cadmium on different granulometric soil fractions: Influence of organic matter and temperature. Geoderma, 189-190, 133-143.

Scarciglia F., Tuccimei P., Vacca A., Barca D., and Soligo M., 2011. Soil genesis, morphodynamic processes and chronological implications in two soil transects of SE Sardinia, Italy: Traditional pedological study coupled with laser ablation ICP-MS and radionuclide analyses. Geoderma, 162, 1-2, 39-64.

Singh B., Farenhorst A., Gaultier J., Pennock D., Degenhardt D., and McQueen R., 2014. Soil characteristics and herbicide sorption coefficients in 140 soil profiles of two irregular undulating to hummocky terrains of western Canada. Geoderma, 232, 107-116.

Skic K., Boguta P., and Sokołowska Z., 2016. Analysis of the sorption properties of different soils using water vapour adsorption and potentiometric titration methods. Int. Agrophys., 30, 369-374.

Soares M., Alleoni L., Vidal-Torrado P., and Cooper M., 2005. Mineralogy and ion exchange properties of the particle size fractions of some Brazilian soils in tropical humid areas. Geoderma, 125, 355-367.

Stemmer M, Gerzabek M., and Kandeler E., 1998. Organic matter and enzyme activity in particle-size fractions of soils obtained after low-energy sonication. Soil Biol. Biochem., 30, 9-17.

Tedrow J.C.F., 1966. Properties of sand and silt fractions in New Jersey soils. Soil Sci., 101 (1), 24-30.

USDA SCS, 1992. Soil survey laboratory methods manual. Soil Survey Investigation Report No 42. Version 2.0. 